\title{
Technical and economic efficiency of technologies for cleaning the air from harmful emissions
}

\author{
Irina Ivanova ${ }^{1, *}$, Elena Golovina ${ }^{1}$, Vyacheslav Manokhin ${ }^{1}$, and Elena Sushko ${ }^{1}$ \\ ${ }^{1}$ Voronezh state technical University, Moscow avenue, 14, Voronezh, 394006, Russia
}

\begin{abstract}
Industrial dust is one of the most common harmful factors in the working environment. Because of it, equipment can fail. When inhaled, it has a negative effect on health and can lead to specific diseases. It reduces visibility in the production area. The aim of the study is to achieve the necessary environmental effect that ensures a decrease in the amount of harmful emissions in the working area, i.e. the ecological effect can be determined by the amount of pollutants, the spread of which is prevented as a result of the installation of highly efficient technological equipment specially designed for these purposes.
\end{abstract}

\section{Introduction}

Mechanical dust is formed as a result of grinding dry materials, sanding, crushing or other technological operations. Currently, there are 4 classes of industrial dust: mechanical, sublimates, fly ash, industrial soot. Sublimates are formed during volumetric condensation of steam or during cooling of gas passing through technological equipment. Fly ash is a noncombustible residue formed from its mineral impurities during combustion and suspended in the flue gas.

Industrial soot is a solid, highly dispersed carbon, which is part of industrial emissions, and is formed during incomplete combustion or during decomposition of hydrocarbons. Pollutants are emitted depending on the type of material being processed. At the same time, the highest dust emission is typical for such processes as abrasive processing of metals, for example, cleaning, sanding, polishing and others [1].

In metallurgical production, including mechanical engineering, exhaust, supply and general ventilation types are used. Exhaust ventilation is formed by removing dusty air from the places of its formation with its subsequent cleaning from dust. At the same time, the supply of fresh air is ensured by the supply ventilation system. The essence of general ventilation is to remove dusty air from the places of formation and supply fresh air, which is pre-purified and heated in the cold season. Thus, the air in the working room is compensated. In case of incomplete compensation of the air removed by the hood, air from the outside will enter the room through various openings. Thus, the supply system delivers more air than is extracted by the ventilation. Consequently, the requirements for the speed of air movement for industrial buildings (no more than $0.3-0.5 \mathrm{~m} / \mathrm{s}$ ) have been established.

* Corresponding author: ivanova-eco@mail.ru 
Very important for the characterization of dust is the degree of its dispersion (grinding), which is determined by the size of the dust particles in the air. The dispersion of dust determines its physicochemical properties and, which is especially important, the ability of dust to stay suspended in the air, as well as greater or less difficulty in separating dust from air.

The degree of dust dispersion can be determined in two ways: either by the number of dust grains of different sizes (as a percentage of their total number), or by the weight of dust grains of a certain size (usually as a percentage of the weight of all dust). These two methods of determination are completely different, since the number of dust grains sharply increases with a decrease in their size. Table 1 shows a comparison of both methods for the same dust.

Table 1. Comparison of both methods for the same dust.

\begin{tabular}{|l|c|c|c|c|c|c|}
\hline \multirow{2}{*}{$\begin{array}{l}\text { Average particle } \\
\text { size in microns }\end{array}$} & 2.5 & 7,5 & 15 & 30 & 50 & 75 \\
\cline { 2 - 7 } & $(0-5)$ & $(5-10)$ & $(10-20)$ & $(20-40)$ & $(40-60)$ & $(60-90)$ \\
\hline $\begin{array}{l}\text { Distribution by the } \\
\text { number of dust } \\
\text { grains in \% }\end{array}$ & 95.87 & 3.00 & 0.66 & 0.24 & 0.09 & 0.14 \\
\cline { 2 - 7 } & \multicolumn{2}{|c|}{98.87} & \multicolumn{4}{|c|}{1.13} \\
\hline $\begin{array}{l}\text { Weight distribution } \\
\text { in \% }\end{array}$ & 1.8 & 1.5 & 2.7 & 8.0 & 13.0 & 73 \\
\cline { 2 - 7 } & \multicolumn{3}{|c|}{3.3} & \multicolumn{3}{|c|}{96.7} \\
\hline
\end{tabular}

Table 1 shows that a large number of small particles - up to 10 microns (98.87\%), as a result, the weight of dust is only $3.3 \%$. On the contrary, the number of particles larger than 10 microns is only $1.13 \%$, while by weight they represent $96.7 \%$ of all dust.

Table 2 shows the weight characteristics of various types of industrial dust found in the air of the working rooms of foundries and in air ducts during testing.

Table 2. Weight characteristics of various types of industrial dust.

\begin{tabular}{|c|c|c|c|c|c|c|}
\hline \multirow[t]{2}{*}{ Dust type and place of its emission } & \multicolumn{6}{|c|}{$\begin{array}{c}\text { Weight percentage of fractions with an average particle } \\
\text { diameter in microns }\end{array}$} \\
\hline & Up to 5 & $5-10$ & $10-20$ & $20-40$ & $\begin{array}{l}40- \\
60\end{array}$ & $\begin{array}{c}\text { More } \\
\text { than } \\
60\end{array}$ \\
\hline Burned earth (from under the knock-out & 6.0 & 3.6 & 15.3 & 16.3 & 6.3 & 52.5 \\
\hline grate) & 3.4 & 4.0 & 17.4 & 21.8 & 8.4 & 45.0 \\
\hline The same (over the filling) & 5.8 & 7.8 & 30.2 & 25.3 & 11.5 & 21.2 \\
\hline The same (above the knock-out grate) & 9.6 & 10.7 & 43.1 & 29.1 & 4.0 & 3.5 \\
\hline The same (deposited on structures) & 6.5 & 5.0 & 4.0 & 14.5 & 20.0 & 50.0 \\
\hline $\begin{array}{l}\text { Blast drum dust (mixed - metal and earth) } \\
\text { Dust trapped in a cyclone }\end{array}$ & 5.2 & 9.7 & 24.4 & 15.4 & 25.5 & 19.8 \\
\hline
\end{tabular}

Table 2 shows that, in terms of weight, the percentage of fine dust varies over a very wide range. The most harmful dust to health (up to 10 microns) is usually contained in an amount of no more than $10-12 \%$, but in some cases, the content of this dust increases sharply.

The industry uses the following dust control methods:

- dust suction systems;

- wet dust extraction of dry material flows;

- all sorts of technological and organizational measures aimed at reducing the concentration of dust in industrial premises [2].

\section{Materials and methods}


The classification of devices and methods of dust collection at industrial enterprises is shown in the diagram (Fig. 1).

Wet dust collectors are widely used in various devices. A characteristic feature is the capture of particles trapped in the liquid and their removal from the device in the form of sediment. Normal water acts as a dusty liquid. Wet devices have the following benefits:

- simple structure;

- relatively low price;

- higher efficiency (when compared with dry-type dust collectors);

- smaller size when compared with tissue and electrostatic ones;

- catches gases.

However, wet dust collectors have disadvantages, such as:

- significant energy consumption;

- the need to organize a water supply system (sedimentation tanks, pumps, coolers, etc.), which makes this type of cleaning expensive to use and maintain

- corrosive wear of gas appliances and pipes;

- harmful effect of moisture drops on the surface of the device [3].

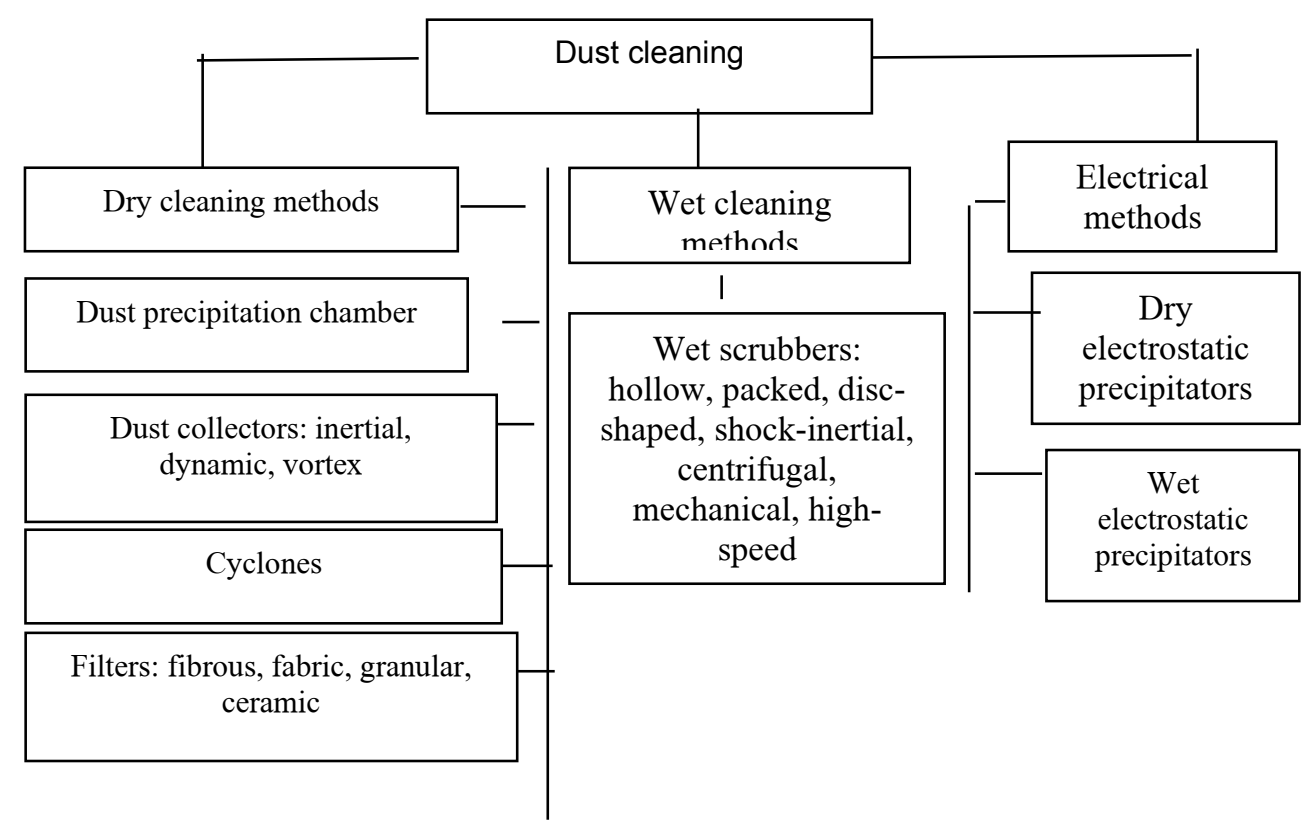

Fig. 1. Classification of dust collection methods

Despite these disadvantages, wet devices are often used in industry, especially where, in addition to cleaning, it is necessary to cool and humidify. Wet machines are installed where there is no place for other equipment. The benefits of wet gas processing are greatly enhanced when it can be connected to an existing water supply system. To collect liquid dust, two collection methods are used: liquid droplets and liquid film. The first method: a stream of powder is passed through a dispersed liquid. During flushing, dust particles enter the liquid droplets and are removed from the gas stream. During changing conditions, dust particles can be nuclei for such condensation. Using this effect can significantly improve dust deposition [4].

Another method is to control the flow of dust particles. The dust is directed to the liquid stream, thereby cleaning.

Depending on the specifics of the collection, wet dust collectors are usually divided into 
two groups:

1) cleaning with liquid

2) use liquid film for cleaning.

\section{Results}

Achieving the required environmental effect is ensured by reducing the amount of harmful emissions in the working area, i.e. the environmental effect can be determined by the amount of pollutants, the spread of which is prevented as a result of the installation of highly efficient technological equipment specially designed for these purposes [5]. The purpose of the invention "Device for wet gas cleaning" is to increase the degree of dust collection by increasing the efficiency of dust coagulation in a two-phase dust-air flow (Fig. 2).

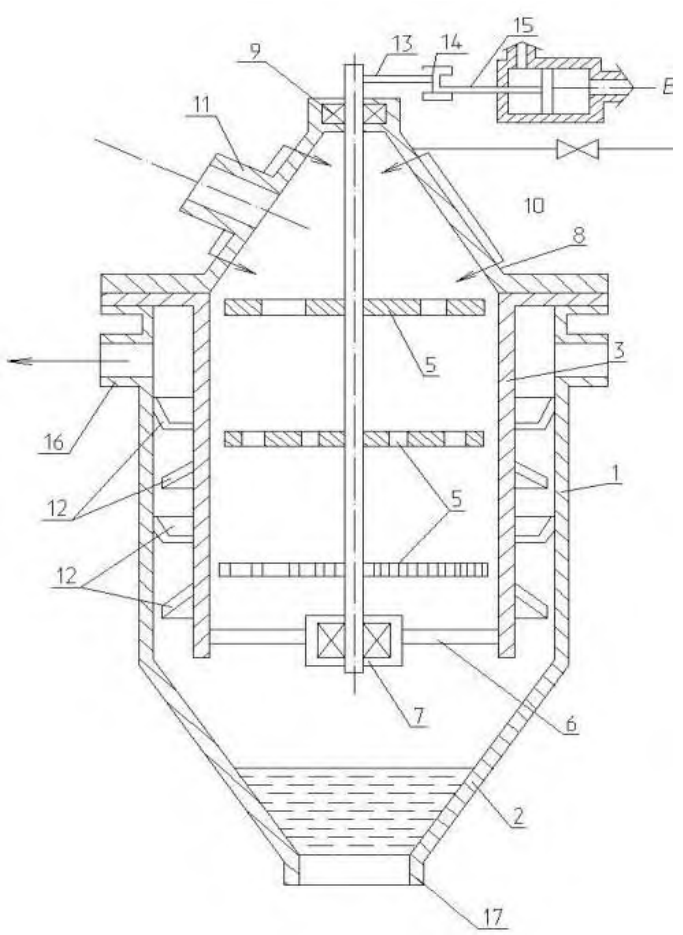

Fig. 2. Device for wet gas cleaning 1- case; 2 - conical bottom; 3 - shaft; 4 - coagulation plates; 5 crosspiece; 6 - bearing; 7 - bearing; 8 - cover; 9 - bearing; 10 - spray nozzles; 11 - inlet pipe; 12 droplet separator; 13 - lever; 14 - pin; 15 - pneumatic cylinder piston; 16 - outlet branch pipe; 17 branch pipe for sludge removal.

"Device for wet gas cleaning" (Fig. 3) refers to the technique of wet cleaning of gas from solid impurities and can be used at enterprises for the production of casting. The aim of the invention is to increase the degree of dust collection also by providing intensive coagulation of dust particles in a humidified gas-air flows. 

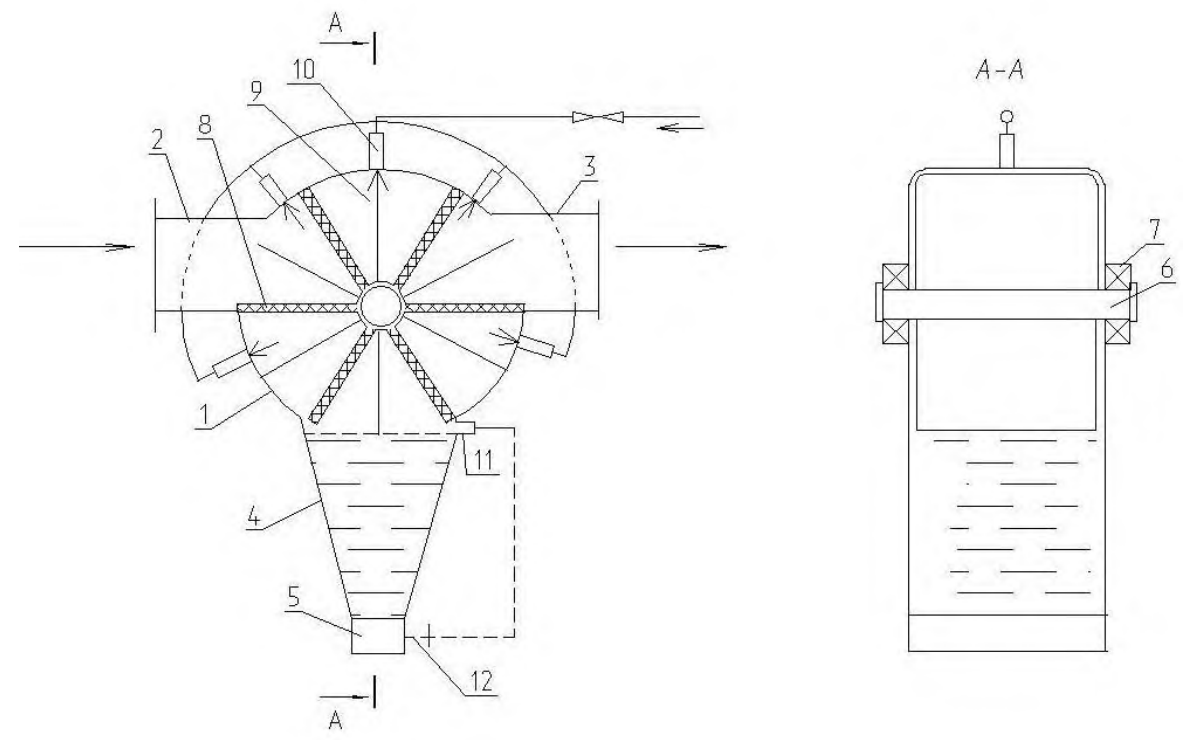

Fig. 3. Device for wet gas cleaning: 1 - case; 2-3 - inlet and outlet branch pipe; 4 - conical bottom; 5 - branch pipe for sludge discharge; 6 - shaft; 7 - bearings; 8 - mesh blade; 9 - disk; 10 - water spray nozzle; 11 - sludge level indicator; 12 - valve.

Capital costs:

$$
\mathrm{CC}=\text { CDC. }+ \text { Cs.p., }
$$

where CDC - cost of a dust catcher;

Cs.p. - cost of the sludge pit.

The guaranteed amortization period of the equipment is 10 years.

Operating costs are determined by the cost of electricity and the additional payment of the operator servicing the device $\Delta Z_{o}$ (unchanged):

$$
\Delta Z_{o}=C_{e}+C_{m}
$$

where $\mathrm{Ce}$ - electricity cost;

$\mathrm{Cm}$ - cost of maintaining the device.

The annual efficiency of measures to protect the atmosphere from dust emissions $\mathrm{E}$ is determined by the formula

$$
\mathrm{E}=\Delta_{\mathrm{Pm}}-\mathrm{CC}-\Delta_{\mathrm{Z}}
$$

where $\Delta \mathrm{Pm}$ - prevented environmental damage from emissions of pollutants, thousand rubles;

$\Delta_{Z}$ - additional annual costs required for the implementation of environmental protection measures (payment of the operator servicing the device), thousand rubles.

The economic assessment of the annual damage $\mathrm{P}_{\mathrm{m}}$, rubles/year, from the annual emission of pollutants into the atmosphere by some source is determined by the formula

$$
\mathrm{P}_{\mathrm{m}}=\gamma \cdot \sigma \cdot f \cdot \mathrm{M}_{\mathrm{red} \Sigma}
$$


where $\sigma$ - coefficient characterizing polluting area ( 4 for industrial area), $f$ - coefficient characterizing the scattering of boundaries (equal to 2),

$\mathrm{M}_{\mathrm{red} \Sigma}$ - total gross emission reduced by the aggressiveness of pollutants.

The total gross emission reduced by the aggressiveness of pollutants is determined by the formula

$$
\mathrm{M}_{\mathrm{red} \Sigma}=\sum_{i=1}^{n} A_{j i} \cdot M_{j i},
$$

where $\mathrm{i}$ - emission source number; $\mathrm{j}$ - ingredient index;

$\mathrm{A}_{\mathrm{ji}}$ - indicator of the relative hazard (aggressiveness) of the $\mathrm{i}$-th pollutant.

For every pollutant

$$
\mathrm{A}_{\mathrm{ji}}=f(1 / \mathrm{MPC})
$$

$\mathrm{M}_{\mathrm{ji}}$ - total mass of the annual emission of the $\mathrm{i}$-th pollutant, $\mathrm{t} / \mathrm{year}$ :

$$
\mathrm{M}_{\mathrm{ji}}=\mathrm{G}_{\mathrm{ji}} \cdot q_{\mathrm{ji}}
$$

Let's make an estimate of $\mathrm{M}_{\mathrm{i}}$ for foundry dust (section for removing casting from molds). $\mathrm{M}_{\mathrm{i}}$ is find by the formula

$$
\mathrm{M}_{\mathrm{i}}=\mathrm{t} \cdot \mathrm{M}
$$

where $\mathrm{t}$ - equipment operating time per year.

When replacing a dry dust collector with a wet one, the breakthrough rate will be $1.5 \%$, therefore

$$
\Delta \phi=31.5-1.5=30 \%
$$

The annual dust emission

$$
\mathrm{M}=4.167 \cdot 3600 \cdot 1.7 \cdot 260 \cdot 10^{-6}=6.63 \mathrm{t} / \text { year. }
$$

Assessment of the annual efficiency of measures when using a dust collector:

$$
\mathrm{E}=\Delta_{\mathrm{Pm}}+\Delta_{\mathrm{Sm}}-\mathrm{Fa}(\mathrm{CDC}+\mathrm{Cs} . \mathrm{p} .+\mathrm{Cm})-(\mathrm{Ce}+\mathrm{C} 0)
$$

where $\Delta_{\mathrm{Pm}}$ - prevented environmental damage due to dust removal from the emission, thousand rubles;

$\Delta \mathrm{Sm}$ - economic effect when using the captured (recycled) dust when switching to DC; $\mathrm{Fa}$ - amortization factor.

Comparing the basic option with the proposed option, we obtain an economic effect from the introduction of DC.

Installation of the proposed device will reduce the damage to the environment and increase the amount of recycled dust [6].

\section{Conclusions}

A priority dust collection device of high efficiency (98-99\%) has been proposed, which ensures a decrease in the amount of dust in the emission to the level of SNiP 2.04.05-86 requirements, and at the working area of the enterprise - to concentrations not exceeding 
MPCw.a.

\section{References}

1. S. E. Andreev, Metody opredeleniya frakcionnyh sostavov, Gornyj zhurnal, 11, 32 - 36 (1951)

2. S. V. Belov, Ohrana okruzhayushchej sredy, 2-e izd., 319 (Moscow, Vyssh. shk., 1991)

3. E. I. Golovina, Opasnye i vrednye faktory litejnogo proizvodstva i ih vliyanie na sostoyanie atmosfery v rabochej zone, Vestnik tekhnologicheskogo universiteta, 19(23), 126-131 (2016)

4. E. I. Golovina, V. Ya. Manohin, I. A. Ivanova, Ocenka opasnyh faktorov litejnogo proizvodstva. Kompleksnye problemy tekhnosfernoj bezopasnosti - materialy Mezhdunarodnoj nauchno-prakticheskoj konferencii, 170-173 (2016)

5. I. A. Ivanova, Ocenka dispersnogo sostava pyli uchastka chernogo lit'ya, 10, 2(45), 200204 (Vestnik DGTU, 2010)

6. I. Ivanova, E. Golovina, K. Kulakov, A. Sorokin, The analysis of disperse and elemental composition of dust from drobestry installations of foundry at the production of construction structures for altitude buildings E3S Web of Conferences, 02012 (2018)

7. I. Ilin, V. Vasilenok, R. Marchenko, Use of renewable energy and tax burden on $\mathrm{CO} 2$ emissions in industrial enterprises, E3S Web of Conferences, 110, 0210 (2019)

8. A. Poljanskihh, A. Levina, A. Dubgorn, Investment in renewable energy: Practical case in Estonia, MATEC Web of Conferences, 193, 05065 (2018) 